\title{
Analysis of the effects of temperature and light after planting on bud blasting in Iris hollandica ${ }^{1}$
}

\author{
E. J. Fortanier and A. Zevenbergen
}

Department of Horticulture, Agricultural University, Wageningen, the Netherlands

Received: 23 March 1973

\section{Summary}

Bud blasting in Dutch irises is primarily caused by too high temperatures and insufficient light or moisture after planting. Quantitative aspects of temperature and light influences have been studied under controlled conditions. The optimum temperature for the earliest flowering and minimum daily light energy required to prevent bud blasting as much as possible, cannot be given. They depend on too many other factors such as cuitivar, bulb size, storage and even on pre-harvest conditions. However, the following trends were observed.

Increased temperatures accelerate flowering and augment minimum daily light requirement. Only a specific combination of temperature and light intensity gives the smallest total light energy requirement from sprouting till flowering, which eventually determines the necessity of additional light. The optimum levels of temperature and light change during plant growth and depend on the acceptable percentage of flowering.

Sensitivity to high temperature and insufficient light increases with plant development until an optimum is reached which coincides with the stage of largest stem elongation. Comparing similar daily light energies or temperatures, intensity and duration of light as well as day and night temperature are within certain limits of a comparable importance regarding either time of flowering or percentage of bud blasting.

Photoperiod has no clear effect on both phenomena, while these are more affected by air temperature than by soil temperature. Sum of temperature till flowering is only constant for each planting and is not correlated with bud blasting. An increase of air temperature during the day as compared with one during the night only occasionally produced more bud blasting. A possible explanation is sought in the occurrence of an unfavourable positive difference between air and soil temperature during the light period.

\section{Introduction}

In bulbous iris the development of a bud into a flower may fail either partially or completely. This failure, abortion or blasting, may occur in all developmental stages from the completion of bud initiation until flowering (Elliot, 1943; Kamerbeek, 1965, p. 340; Rees, 1972, p. 247). An incomplete initiation, an imperfect opening or an

1 Publication 387, Laboratorium voor Tuinbouwplantenteelt, Landbouwhogeschool, Wageningen, the Netherlands. 
insufficient protrusion of the flower from the two spatha, which is often accompanied by discolouring, are considered as marginal cases of bud blasting. Excluded are cases in which an expected initiation did not take place. For these the term 'blindness' should be reserved (Kamerbeek, pers.comm.).

Blasting of the bud may be induced either before or after its initation, which mostly occurs shortly after planting. Cultivar, bulb size, conditions before and during bulb storage, and growth conditions after planting, are important (Beyer, 1952; Blaauw, 1934, 1935, 1941; Halevy et al., 1964; Hartsema \& Luyten, 1962; Kamerbeek \& Beyer, 1964; Walla \& Kristoffersen, 1969). Blasting is very common during early and late flowering. 'Wedgwood' and its mutants 'Dominator' and 'Ideal' are considered as by far the least susceptible cultivars. Compared with these 'Prof. Blaauw' and 'Imperator' flower with more difficulty under poor light conditions (Fortanier, unpublished; Hartsema \& Luyten, 1955a, b, 1961; van de Nes, 1962).

Most of the literature on bud blasting deals with the causes of it before bud initiation and emphasizes the effects of bulb size and storage temperature (Blaauw et al., 1936b; Hartsema \& Luyten, 1962; Kamerbeek, 1963b; Stuart et al., 1955). Flower initiation is ensured when harvested bulbs of a sufficient size are first stored at higher temperatures $\left(35-17^{\circ} \mathrm{C}\right.$ ) until more than 3 leaves have been initiated (to prevent the initiation of a terminal daughter bulb) and then at lower temperatures $\left(17-9{ }^{\circ} \mathrm{C}\right)$ (Halevy et al., 1963; Kamerbeek, 1963b, 1965; Kamerbeek \& Beyer, 1964; Kimura \& Stuart, 1972). These treatments may also lower the change of bud blast after planting. Research in this field, started in 1928 by Blaauw and his co-workers, is being continued and leads to an almost continuous alteration of the advised standard treatments considered better for a more rapid flowering with less failures (Durieux, 1972b; Kamerbeek \& Beyer, 1964; Stuart \& Gould, 1967). In general, storage temperatures leading to a suppressed leaf growth after planting may limit bud blasting when plants are forced under poor light conditions. Retardation of the bulbs by high storage temperatures $\left(25-30^{\circ} \mathrm{C}\right.$ ) increases the risk of bud blasting (Durieux, 1972a; Hartsema \& Luyten, 1961). However, when forced to flower from December till November under similar conditions, the chance of bud blasting at first decreases and increases only after a certain period of retardation (Fortanier, unpublished).

Climatic conditions after planting are variable and more difficult to control than storage conditions. This may explain why research into the causes of bud blasting that operate after planting, is rathed limited. The pioneers in this field were again Blaauw, Hartsema and Luyten. Shortage of water, insuffient light and high temperatures are the best known causes of bud blasting (Hartsema \& Luyten, 1953, 1955a, b, 1961, 1962; Kamerbeek, 1966, 1969; Kamerbeek \& Beyer, 1964; Mayak \& Halevy, 1971). Light requirement increases at high temperatures and both factors are of a comparable importance. Only in a few cases attention has been paid to the importance of day and night temperature, air and soil temperature, and photoperiod (Cathey, 1954; Kamerbeek, 1963a, 1969; Kamerbeek \& Beyer, 1964; van de Nes, 1962).

Research on the physiological background of bud blasting in iris is of a more recent date. Bud blasting seems to be correlated with the accumulation and distribution of assimilates. A shortage of transportable sugars is the most plausible cause (Kamerbeek, 1965 , p. 341). The amount required for flowering depends on factors such as storage conditions and time of forcing. These assimilates are drawn in different proportions from the reserves in the mother bulb and from the leaves, which for their formation already utilized part of the reserves (Kamerbeek, 1966, 1969; Wassink, 1961, 1969; Wassink \& Wassink-van Lummel, 1952). When flowering is required under poor winter 
light conditions, forcing conditions have to be chosen in such a way that a maximum part of total available assimilates is diverted to stem and flower development, while other morphogenetic processes including the growth of leaves and daughter bulbs receive the minimum (see below). Very little is known about the fundamentals of mobilization, distribution and utilization (Kamerbeek, 1962; Rodrigues Pereira, 1970; Wassink, 1961). It is supposed that hormones play a role. Of these growth regulators, ethylene seems to be particularly important in bud blasting (Stuart et al., 1966).

\section{Scope of research}

When the bulbs are able to reach anthesis, prevention of bud blasting will mainly depend on the climatic conditions after planting. As outlined before, these have been the subject of research which, however, was mostly directed to the effect of individual factors and very little towards their mutual relationships. Therefore, quantitative information on the interaction between light and temperature is very scarce. Because of the dependence on other conditions, experimental results are difficult to reproduce quantitatively and many replications are required to form a better notion.

We tried to acquire more information by forcing bulbs of different cultivars prepared for early or late flowering, under controlled conditions of temperature and light in different combinations. In particular, the influence of duration and intensity of light and of air and soil temperature during the day and the night were compared.

As this paper is intended as a general survey of our work in this field, some representative experiments will be discussed without a mathematical analysis or physiological explanation. The results provide information for an optimal forcing of Dutch irises and moreover may help to evaluate a model of the physiology of bud blasting.

\section{Material and methods}

Most of the experiments were done in a phytotron (Doorenbos, 1964) with a radiant flux density of $40 \mathrm{~W} \mathrm{~m}^{-2 *}$ from fluorescent Philips TL 55. Available space limited the number of cultivars and plants per treatment. The latter exceeded 24 in most cases. Conditions during storage and forcing and number of plants are given at the legends of tables and figures.

The parameter for bud blasting depended on the results. Each trial is more or less a gamble, because an experiment with a result of either $100 \%$ flowering or $100 \%$ blasting prevents conclusions. Moreover the percentage of blasted buds is a poor quantitative measure because the individual bud can only open or blast, without intermediate values. These disadvantages have been overcome as much as possible in several ways:

1. Normally Dutch iris forms an inflorescence instead of a single flower (Luyten, 1942). Susceptibility for blasting increases from the first or terminal bud to the side buds of higher order, but their reactions to adverse conditions are similar (Blaauw, 1935, p. 52; Fortanier, unpublished; Hartsema \& Luyten, 1961; Luyten, 1942, p. 16). If necessary,

* $1 \mathrm{~W} \mathrm{~m} \mathrm{~W}^{-2}\left(=1 \mathrm{~J} \mathrm{~m}^{-2} \mathrm{~s}^{-1}\right)=1000 \mathrm{erg} \mathrm{cm}^{-2} \mathrm{~s}^{-1} \approx 0.086 \mathrm{cal} \mathrm{cm}^{-2} \mathrm{~h}^{-1}$. The radiant flux density has been expressed as erg $\mathrm{cm}^{-2} \mathrm{~s}^{-1}$ by Wassink, and as cal $\mathrm{cm}^{-2} \mathrm{~h}^{-1}$ by others. We conversed their figures to $\mathrm{W} \mathrm{m}^{-2}$, belonging to the SI units. 
blasting percentages of the second and even the third bud have been used instead of those of the first one.

2. As growth conditions are less favourable, the bud aborts at an earlier stage or a smaller size, which is accompanied by an earlier termination of stem elongation and leaf growth (Kamerbeek, 1966; this paper). Similar effects were found after an artificial removal of the bud at progressively earlier stages of its development (Fortanier, unpublished). Length of bud or stem therefore reflects time of abortion and is considered to be a much better quantitative measure than the percentage of blasting.

The figures presented refer to plants which initiated at least one flower. Choice of bulb size and pre-treatment were such as to limit the number of vegetative plants to the utmost. To ensure equal sprouting, the bulbs have been graded according to weight, treated with fungicides and peeled before planting. In some cases the experiments started after the initiation of the flower bud, about three weeks after planting.

\section{Results and discussions}

\section{Effect of temperature and light}

Non retarded bulbs of 'Dominator', 'Prof. Blaauw' and 'Imperator', prepared for early flowering, were planted in the phytotron at 6 temperatures from 9 to $24{ }^{\circ} \mathrm{C}$ and 8,12 and $16 \mathrm{~h}$ of fluorescent light per day. The daily energy corresponds with the average values in a greenhouse in the Netherlands at the end February, the beginning and the middle of March, respectively. Excepted some plants at 21 and $24{ }^{\circ} \mathrm{C}$ in 8 and $12 \mathrm{~h}$

Table 1. Effect of temperature and light on percentage of blasting of 2 nd bud and the number of days from planting till $50 \%$ flowering of 1 st bud. Storage 2 weeks at $35^{\circ} \mathrm{C}+2$ weeks at $17{ }^{\circ} \mathrm{C}+6$ weeks at $9{ }^{\circ} \mathrm{C}$; planted $63-12-17 ; 8$ bulbs/treatment; light energy flux density $40 \mathrm{~W} \mathrm{m-?}$.

\begin{tabular}{|c|c|c|c|c|c|c|c|c|c|c|c|c|c|c|}
\hline \multirow{2}{*}{$\begin{array}{l}\text { Light } \\
\text { (h) }\end{array}$} & \multicolumn{7}{|c|}{ Belasting $(\%)$ at } & \multicolumn{7}{|c|}{ Days at } \\
\hline & $9^{\circ} \mathrm{C}$ & $12^{\circ} \mathrm{C}$ & $15^{\circ} \mathrm{C}$ & $18^{\circ} \mathrm{C}$ & $21{ }^{\circ} \mathrm{C}$ & $24^{\circ} \mathrm{C}$ & mean & $9^{\circ} \mathrm{C}$ & $12^{\circ} \mathrm{C}$ & $15^{\circ} \mathrm{C}$ & $18^{\circ} \mathrm{C}$ & $21^{\circ} \mathrm{C}$ & $24^{\circ} \mathrm{C}$ & mean \\
\hline \multicolumn{15}{|c|}{ 'Dominator' } \\
\hline 8 & 0 & 0 & 88 & 100 & 100 & 100 & 65 & 142 & 117 & 78 & 59 & 54 & 49 & 83 \\
\hline 12 & 0 & 0 & 25 & 38 & 100 & 100 & 44 & 133 & 110 & 72 & 57 & 51 & 49 & 79 \\
\hline 16 & 0 & 0 & 0 & 0 & 75 & 88 & 27 & 131 & 105 & 70 & 57 & 51 & 49 & 77 \\
\hline Mean & 0 & 0 & 38 & 46 & 92 & 96 & 45 & 135 & 111 & 73 & 58 & 52 & 49 & 80 \\
\hline \multicolumn{15}{|c|}{ 'Prof. Blaauw' } \\
\hline 8 & 13 & 25 & 75 & 63 & 100 & 100 & 63 & 152 & 128 & 85 & 65 & 58 & 50 & 90 \\
\hline 12 & 0 & 0 & 0 & 38 & 75 & 88 & 34 & 148 & 119 & 82 & 64 & 56 & 51 & 87 \\
\hline 16 & 0 & 0 & 0 & 0 & 38 & 38 & 13 & 147 & 113 & 73 & 62 & 54 & 51 & 83 \\
\hline Mean & 4 & 8 & 25 & 34 & 71 & 75 & 37 & 149 & 120 & 80 & 64 & 56 & 51 & 87 \\
\hline \multicolumn{15}{|c|}{ 'Imperator' } \\
\hline 8 & 50 & 50 & 25 & 88 & 88 & 100 & 67 & 160 & 141 & 111 & 86 & 84 & 73 & 109 \\
\hline 12 & 0 & 0 & 0 & 13 & 88 & 100 & 34 & 158 & 135 & 103 & 84 & 84 & 72 & 106 \\
\hline 16 & 0 & 0 & 0 & 0 & 75 & 100 & 29 & 155 & 132 & 96 & 84 & 83 & 68 & 103 \\
\hline Mean & 17 & 17 & 8 & 34 & 84 & 100 & 43 & 158 & 136 & 103 & 85 & 84 & 71 & 106 \\
\hline $\begin{array}{l}\text { Total } \\
\text { mean }\end{array}$ & 7 & 8 & 24 & 30 & 82 & 90 & 42 & 147 & 122 & 86 & 69 & 64 & 65 & 91 \\
\hline
\end{tabular}


EFFECTS OF TEMPERATURE AND LIGHT AFTER PLANTING ON BUD BLASTING OF IRIS

Table 2. Effect of light and temperature on percentage of blasting of 1 st bud and stem length of plants with bud blasting. Storage at $30^{\circ} \mathrm{C}+6$ weeks at $17{ }^{\circ} \mathrm{C}$; planted 67-08-03; 54 'Wedgwood' bulbs per treatment; light energy flux density $40 \mathrm{~W} \mathrm{m-2}$.

\begin{tabular}{|c|c|c|c|c|c|c|c|c|c|c|c|c|c|c|}
\hline \multirow{2}{*}{$\begin{array}{l}\text { Temp. } \\
\left({ }^{\circ} \mathrm{C}\right)\end{array}$} & \multicolumn{7}{|c|}{ Blasting $\%$ at $\ldots$ h light } & \multicolumn{7}{|c|}{ Stem length at $\ldots h$ light } \\
\hline & 2 & 4 & 8 & 12 & 16 & 24 & mean & 2 & 4 & 8 & 12 & 16 & 24 & mean \\
\hline 15 & 100 & 95 & 68 & 4 & 2 & 0 & 45 & 8 & 15 & 38 & 34 & 54 & $(60)$ & 35 \\
\hline 18 & 100 & 100 & 100 & 80 & 6 & 0 & 64 & 2 & 13 & 20 & 19 & 27 & (51) & 22 \\
\hline 21 & 100 & 100 & 100 & 90 & 56 & 17 & 77 & 2 & 2 & 9 & 12 & 26 & 29 & 13 \\
\hline 24 & 100 & 100 & 100 & 100 & 100 & 100 & 100 & 1 & 1 & 3 & 6 & 7 & 24 & 7 \\
\hline Mean & 100 & 99 & 92 & 68 & 41 & 29 & 72 & 3 & 8 & 18 & 18 & 28 & 41 & 19 \\
\hline
\end{tabular}

light (TL), all plants produced a first flower. Differences regarding the second bud were greater. Table 1 gives the percentages of blasted second buds and number of days from planting to $50 \%$ open flowers of the main buds, for each of the cultivars.

Blasting of the second bud was promoted by high temperatures and short irradiations. Within certain limits the unfavourable effect of high temperatures can be diminished or even nullified by more light, and the effect of low light energies by lower temperatures. In the case of 'Dominator' $1.17 \mathrm{MJ} \mathrm{m}^{-2}$ day ${ }^{-1 *}$ was sufficient for almost $100 \%$ flowering of the main buds within 7 weeks from planting at $24^{\circ} \mathrm{C}$. Regarding blasting percentage, differences with the two other cultivars were small. In most other experiments, however, 'Dominator' was the least susceptible cultivar with the lowest light requirement.

Flowering was accelerated by high temperatures, especially in the range of 9 to $18{ }^{\circ} \mathrm{C}$. The somewhat earlier flowering in longer light periods could also be a result of a small increase in air and soil temperature by the light. In this and most other experiments 'Dominator' flowered earlier than the other cultivars. It differs from the others in a smaller number of leaves which grow more rapidly, especially at a low temperature. Therefore 'Dominator' seems to have a lower minimum temperature for growth.

In a similar experiment with retarded bulbs of 'Wedgwood' we also measured stem length of the non-flowering plants as a parameter for the stage of development at which the bud blasted. Percentage of blasting of the first bud and stem length are presented in Table 2. Blasting was much more severe than in the preceding experiment: temperature had to be lowered to $15^{\circ} \mathrm{C}$ while daylength had to be extended to $12 \mathrm{~h}$ (1.76 $\mathrm{MJ} \mathrm{m}^{-2}$ day $^{-1}$ ) to reach also $100 \%$ flowering within 11 weeks from planting. As 'Wedgwood' and 'Dominator' are almost identical, these differences indicate an increased light requirement of retarded bulbs. Apart from this, the effects of temperature and light were similar: more buds blasted in an earlier stage of development at higher temperatures and lower energies of light. In $24 \mathrm{~h}$ light at 15 and $18{ }^{\circ} \mathrm{C}$ all the buds opened but some could not be regarded as full-grown. Stem length of these plants is presented between brackets. The figures indicate that similar blasting percentages coincide with different stem length. The latter therefore represent a better measure. The more unfavourable the conditions, the earlier the bud will blast and the shorter the stem will remain.

Discussion. These results are in general accordance with those of other publications, discussed in the introduction. Light requirement per day increases at high temperatures

* $1 \mathrm{MJ}$ (megajoule) $=10^{5} \mathrm{~J} ; 1 \mathrm{MJ} \mathrm{m-2}=10^{7} \mathrm{erg} \mathrm{cm}^{-2} \approx 23.9 \mathrm{cal} \mathrm{cm}^{2}$. 
and depends on cultivar and duration of storage. Hartsema \& Luyten (1961) mentioned a light requirement for $100 \%$ flowering of the first bud of 'Imperator', ranging from 0.34 to $1.97 \mathrm{MJ} \mathrm{m}^{-2}$ day-1 $^{-1}$ at a forcing temperature from 15 to $17^{\circ} \mathrm{C}$. The variability depends on conditions before and after planting, while daylength was also a very important factor. We will discuss this aspect later. However, light was measured with a spherical light meter and the values found by Hartsema \& Luyten are therefore expressed per sphere of $1 \mathrm{~cm}^{2}$ cross-section. They would have been lower if measured in a plane. A value of $0.34 \mathrm{MJ} \mathrm{m}^{-2} \mathrm{day}^{-1}$ must therefore be considered exceptionally low. The fact that bulbs were planted at $9{ }^{\circ} \mathrm{C}$ and transferred to $15{ }^{\circ} \mathrm{C}$ after the sprout had reached a certain length, could have lowered the light requirement. Kamerbeek (1969) who did his experiments in the same phytotron, mentioned a minimum light requirement of $1.26 \mathrm{MJ} \mathrm{m}^{-2}$ day-1 $^{-1}$ for non-retarded bulbs of 'Wedgwood' planted at $15^{\circ} \mathrm{C}$, and this is very close to our value of $1.17 \mathrm{MJ} \mathrm{m}^{-2} \mathrm{day}^{-1}$, but at $24{ }^{\circ} \mathrm{C}$. We consider $0.84 \mathrm{MJ} \mathrm{m}^{-2}$ day-1 as a minimum value at $15^{\circ} \mathrm{C}$.

\section{Effect of photoperiod}

In the preceding experiments daily light energy was regulated by varying the length of the daily irradiation. This introduces the photoperiod as a factor that could have influenced the results. To investigate this, retarded bulbs of six cultivars were forced in summer at $8 \mathrm{~h}$ of sunlight, extended daily with $0,4,8$ or $12 \mathrm{~h}$ of weak incandescent light. During the $8 \mathrm{~h}$ of sunlight the plants were in the open. Temperature was not regulated but similar for all groups. Because all combinations produced less than $10 \%$ blasting of the first bud, the percentages are presented for the second bud in Table 3 , together with the number of days from planting to $50 \%$ open flowers from the first bud. The figures show that 'Dominator' produced the lowest percentage of blasting together with 'Prof. Blaauw' and flowered much earlier than the other cultivars. In general, photoperiods of 16 and $20 \mathrm{~h}$ produced a little more blasting, especially in 'Dominator'. These small differences could have been caused by a small increase in air temperature during the additional irradiation, but this is only partially supported by the differences in flowering time. Therefore, the experiment was repeated several times.

Table 4 presents the results with retarded bulbs of 'Dominator' forced in 6 and $9 \mathrm{~h}$ of summer light, both extended with weak incandescent light to photoperiods of 10 , 13,16 and $19 \mathrm{~h}$. The figures clearly demonstrate that light requirement for flowering

Table 3. Effect of photoperiod on percentage of blasting of 2 nd bud and number of days from planting to $50 \%$ open flowers from the 1 st bud. Storage at $30{ }^{\circ} \mathrm{C}+9$ weeks at $17{ }^{\circ} \mathrm{C}$; planted $65-06-22$; 40 bulbs per treatment; $8 \mathrm{~h}$ daylight extended with $0,4,8$ and $12 \mathrm{~h}$ of weak incandescent light.

\begin{tabular}{|c|c|c|c|c|c|c|c|c|c|c|}
\hline \multirow[t]{2}{*}{ Cultivar } & \multicolumn{5}{|c|}{ Blasting (\%) at photoperiod } & \multicolumn{5}{|c|}{ Days at photoperiod } \\
\hline & $8+0$ & $8+4$ & $8+8$ & $8+12$ & mean & $8+0$ & $8+4$ & $8+8$ & $8+12$ & mean \\
\hline 'Dominator' & 50 & 75 & 94 & 92 & 78 & 50 & 49 & 49 & 47 & 49 \\
\hline 'White Superior' & 80 & 82 & 95 & 88 & 86 & 73 & 71 & 71 & 70 & 71 \\
\hline 'La Marquette' & 100 & 100 & 97 & 100 & 99 & 84 & 81 & 82 & 80 & 82 \\
\hline 'Imperator' & 77 & 69 & 84 & 91 & 80 & 84 & 83 & 79 & 78 & 81 \\
\hline 'Van Vliet' & 95 & 95 & 87 & 94 & 93 & 85 & 82 & 84 & 81 & 83 \\
\hline 'Prof. Blaauw' & 72 & 55 & 82 & 85 & 74 & 88 & 85 & 86 & 83 & 86 \\
\hline Mean & 79 & 79 & 89 & 92 & 85 & 77 & 75 & 75 & 73 & 75 \\
\hline
\end{tabular}


Table 4. Effect of light energy and photoperiod on percentage of blasting of 1st, 2nd and 3rd bud and days from planting to opening of $50 \%$ of 1 st and 2 nd flower. Storage at $30{ }^{\circ} \mathrm{C}+9$ weeks at $17^{\circ} \mathrm{C}$; planted at 66-06-29; 50 bulbs of 'Dominator' per treatment; 6 or $9 \mathrm{~h}$ of daylight extended with weak incandescent light.

\begin{tabular}{|c|c|c|c|c|c|c|c|}
\hline \multirow{2}{*}{$\begin{array}{l}\text { Sunlight }+ \\
\text { incandescent } \\
\text { light }(h)\end{array}$} & \multicolumn{4}{|c|}{ Blasting (\%) } & \multicolumn{3}{|c|}{ Days to opening } \\
\hline & $\begin{array}{l}\text { 1rd } \\
\text { bud }\end{array}$ & $\begin{array}{l}\text { 2nd } \\
\text { bud }\end{array}$ & $\begin{array}{l}\text { 3rd } \\
\text { bud }\end{array}$ & mean & $\begin{array}{l}\text { 1st } \\
\text { bud }\end{array}$ & $\begin{array}{l}\text { 2nd } \\
\text { bud }\end{array}$ & $\begin{array}{l}\text { difference } \\
\text { days }\end{array}$ \\
\hline $\begin{array}{l}6+4 \\
6+7 \\
6+10 \\
6+13\end{array}$ & $\begin{array}{l}0 \\
6 \\
0 \\
0\end{array}$ & $\begin{array}{l}60 \\
62 \\
75 \\
77\end{array}$ & $\begin{array}{l}100 \\
100 \\
100 \\
100\end{array}$ & $\begin{array}{l}53 \\
54 \\
58 \\
59\end{array}$ & $\begin{array}{l}47 \\
46 \\
46 \\
46\end{array}$ & $\begin{array}{l}51 \\
49 \\
52 \\
50\end{array}$ & $\begin{array}{l}4 \\
3 \\
6 \\
4\end{array}$ \\
\hline Mean & 2 & 69 & 100 & 57 & 47 & 51 & 4 \\
\hline $\begin{array}{l}9+1 \\
9+4 \\
9+7 \\
9+10\end{array}$ & $\begin{array}{l}0 \\
0 \\
0 \\
0\end{array}$ & $\begin{array}{r}7 \\
0 \\
7 \\
14\end{array}$ & $\begin{array}{r}86 \\
96 \\
100 \\
100\end{array}$ & $\begin{array}{l}31 \\
32 \\
37 \\
38\end{array}$ & $\begin{array}{l}47 \\
47 \\
46 \\
46\end{array}$ & $\begin{array}{l}52 \\
52 \\
51 \\
50\end{array}$ & $\begin{array}{l}5 \\
5 \\
5 \\
4\end{array}$ \\
\hline Mean & 0 & 7 & 95 & 34 & 47 & 51 & 5 \\
\hline $\begin{array}{l}\text { Control } \\
\text { outside }\end{array}$ & 0 & 0 & 93 & 31 & 53 & 60 & 7 \\
\hline
\end{tabular}

increases from the first to the third bud. They show no clear effects of photoperiod, neither on percentages of blasted buds, nor on time of flowering. The repeated tendency of a small increase in blasting percentage at a longer photoperiod, is probably due to the small increase in temperature mentioned earlier, which could also explain the small acceleration of flowering. Blasting, particularly of the second bud, was much less in $9 \mathrm{~h}$ than in $6 \mathrm{~h}$ of daylight, due to the difference in light energy only. The control group remained outside all the time and flowered 6 to 9 days later because of the lower night temperatures, but with about the same percentage of bud blasting as the 9-h group.

Discussion. The fact that light energy had a distinct effect on bud blasting, but not on flowering time, confirms the results discussed earlier. No indication has been found of an influence of the photoperiod. The latter term is used instead of 'daylength' if we refer to the duration of light independent of light energy. The absence of an effect confirms the conclusion of Kamerbeek (1969) that 'a photoperiodic long day effect does not seem to be involved'.

\section{Effect of daylength and light intensity}

If the daily light energy is kept similar, it is to be expected that a long illumination with weak light will be more effective than a shorter illumination with stronger light. This aspect could be investigated more easily after we found that photoperiod has no significant influence. Bulbs of 3 cultivars were planted on 3 dates at the $12 \mathrm{com}$ binations of 4 daylengths and 3 light intensities. As the 9 groups ( 3 cultivars $\times 3$ dates) of plants reacted in a similar way, the results are presented for all the plants as one group. Table 5 presents the blasting percentages of the first bud and the measured 
Table 5. Effect of daylength and light intensity on percentage of blasting of 1 st bud and daily light energy (MJ m-2) actually measured. Several cultivars and storages; 120 bulbs per treatment; planted 65-12-30, 66-02-22 and 66-03-17; temperature $22{ }^{\circ} \mathrm{C}$ and light energy flux density $45 \mathrm{~W} \mathrm{~m}-2$.

\begin{tabular}{|c|c|c|c|c|c|c|c|c|c|c|}
\hline \multirow{2}{*}{$\begin{array}{l}\text { Light } \\
\text { intensity }(\%)\end{array}$} & \multicolumn{5}{|c|}{ Blasting $(\%)$ at $\ldots h$ light } & \multicolumn{5}{|c|}{ Energy $(\mathrm{MJ} \mathrm{m-2})$ at $\ldots h$ light } \\
\hline & 4 & 8 & 12 & 16 & mean & 4 & 8 & 12 & 16 & mean \\
\hline 50 & 94 & 94 & 86 & 85 & 90 & 0.33 & 0.67 & 1.00 & 1.34 & 0.83 \\
\hline 75 & 94 & 92 & 76 & 55 & 79 & 0.50 & 1.00 & 1.46 & 1.97 & 1.23 \\
\hline 100 & 88 & 79 & 67 & 27 & 55 & 0.67 & 1.34 & 1.92 & 2.59 & 1.63 \\
\hline Mean & 92 & 88 & 76 & 56 & 78 & 0.50 & 1.00 & 1.46 & 1.97 & 1.23 \\
\hline
\end{tabular}

daily energies. Within the range investigated there were no specific differences in the effects of duration and intensity of light.

Discussion. Comparing the results of many experiments, either with $16 \mathrm{~h}$ light of different intensities or with different daylengths of the same intensity, Hartsema \& Luyten (1955b, p. 374) concluded: 'It is of great importance, whether the total amount of light is given in a short or long day: the light requirement is significantly higher in longer days.' Their results relate to 'Imperator' at 0.34 to $1.97 \mathrm{MJ} \mathrm{m}^{-2} \mathrm{day}^{-1}$ measured spherically. A conversion to horizontally measured values is practically impossible. It can only be stated that the converted figures will be lower when more reflected light was measured with the pherical sensor (Wassink \& van der Scheer, 1953). Therefore, the conclusion of Hartsema \& Luyten is probably valid only under marginal light intensities. In our opinion the general rule is that an extension of daylength is at least equally effective in lowering the blasting percentage as an increase of light intensity, provided that the intensity is not much below $30 \mathrm{~W} \mathrm{~m}^{-2}$. Within certain limits, energetically as well as photoperiodically, the distribution of a specific light energy over the 24-h period has no influence on the percentage and time of flowering.

\section{The sum of light until flowering}

The preceding experiments indicate that when the temperature is raised, higher daily light energies are required to reach the same percentage of flowering. Because the higher temperature leads to an earlier flowering, the increased energy is given for a smaller number of days, so that the sum of light energy from sprouting till flowering may be higher than, similar to, or lower than the required light-sum at a low temperature. The second possibility of a similar value could indicate that total light requirement is constant at all temperatures. However, this is not the case as can be illustrated with the figures of Table 1 . 'Dominator' produced $12 \%$ second flowers after 78 days at $15^{\circ} \mathrm{C}$ and $8 \mathrm{~h}$ of light. A similar percentage was reached after 49 days at $24^{\circ} \mathrm{C}$ and $16 \mathrm{~h}$ of light. The required total energy sum can be calculated as 91 and $115 \mathrm{MJ} \mathrm{m}^{-2}$, respectively. With regard to light energy the first condition was therefore the more economical, but as will be demonstrated, an increase of temperature may also diminish the light-sum required until flowering.

From a large number of experiments the overall relation between temperature and days to flowering is represented by Curve $A$ in Fig. 1. The overall relation between temperature and the daily light requirement for $50 \%$ flowering of the first bud is 

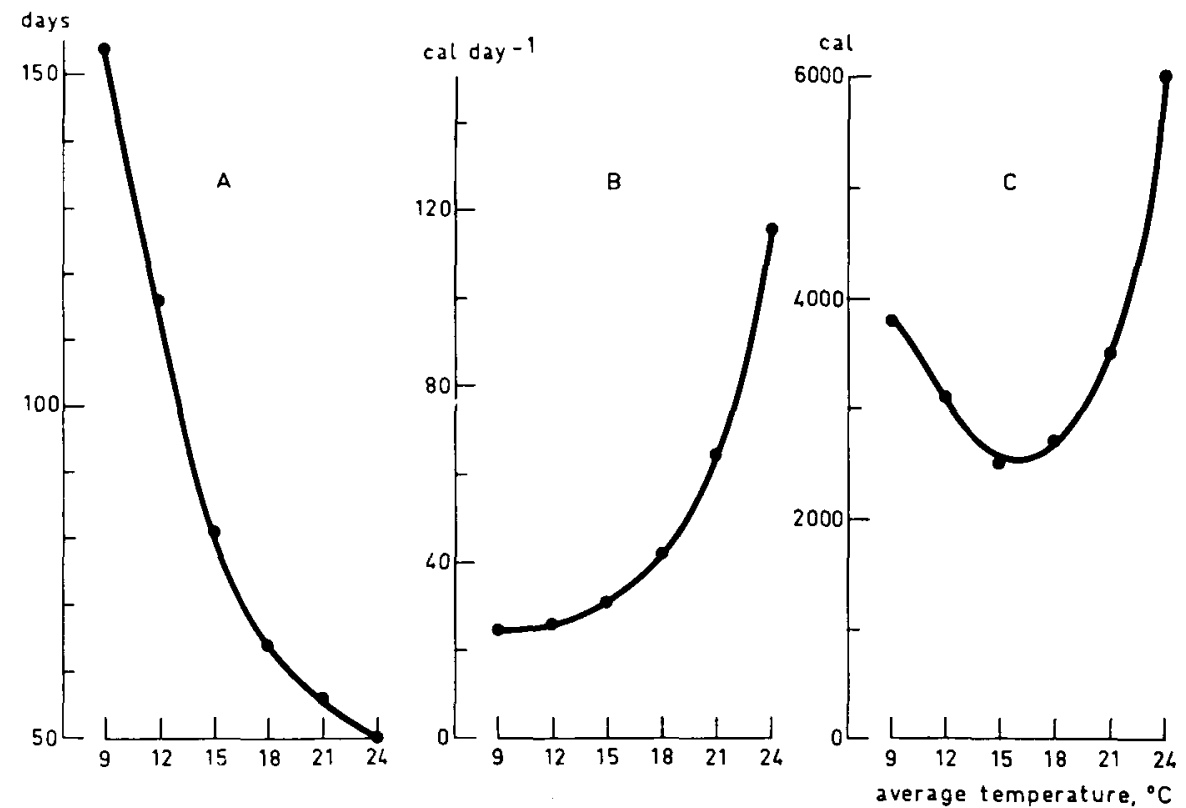

Fig. 1. Averaged for a number of experiments in different years with retarded and non retarded bulbs of different cultivars, the relation between the daily temperature and: A. days from sprouting to flowering; B. daily light requirement for $50 \%$ flowering of the 1st bud; C. total light-sum $(\mathbf{A} \times \mathbf{B})$ from sprouting to flowering. $1 \mathrm{cal} \approx 4.2 \mathrm{~J}$.

represented by Curve B. From $A$ and $B$ the overall relation between temperature and the light-sum until flowering has been calculated. This is represented by Curve $\mathrm{C}$, which has its lowest value at $15^{\circ} \mathrm{C}$.

Discussion. Curve C in Fig. 1 clearly demonstrates that a specific combination of temperature and light energy has to be chosen to arrive at the lowest total light requirement from sprouting till flowering. In practice the choice is almost impossible, because too many factors are involved. It depends amongst others on the acceptable percentage of flowering and on the levels of temperature and light at which this percentage will be reached. For $50 \%$ flowering and low levels of both factors an increase of temperature and light will be at first more economic than a maintenance of the conditions and less if increased too much. At high levels an increase of temperature and light will directly lead to a larger total sum of light, because the daily light requirement increases more rapidly than the acceleration of flowering. It seems worth-while to compile more information for computing the relations more thoroughly for specific cultivars, forcing conditions, stages of growth and time of flowering.

\section{Comparison of day and night temperature effects}

To investigate whether a temperature increase during the day was more detrimental to flowering than one at night, plants were forced at 6 day and night temperatures (DT and NT) ranging from 9 to $24^{\circ} \mathrm{C}$, in all possible combinations. DT and NT each 
Table 6. Effect of day and night temperature (DT, NT) on percentage of blasting of 2 nd bud and days from planting to flowering of 1 st bud. Storage 2 weeks at $35^{\circ} \mathrm{C}+3$ days at $40{ }^{\circ} \mathrm{C}+2$ weeks at $17{ }^{\circ} \mathrm{C}+6$ weeks at $9{ }^{\circ} \mathrm{C}$; planted 68-11-17; 54 'Wedgwood' bulbs per treatment; in phytotron on $68-11-18 ; 12 \mathrm{~h}$ light per day of $40 \mathrm{~W} \mathrm{m-2}$.

\begin{tabular}{|c|c|c|c|c|c|c|c|c|c|c|c|c|c|c|}
\hline \multirow{2}{*}{$\begin{array}{l}\text { DT } \\
\left({ }^{\circ} \mathrm{C}\right)\end{array}$} & \multicolumn{7}{|c|}{ Blasting $(\%)$ at $\ldots{ }^{\circ} \mathrm{C} \mathrm{NT}$} & \multicolumn{7}{|c|}{ Days to flowering at $\ldots{ }^{\circ} \mathrm{C} \mathrm{NT}$} \\
\hline & 9 & 12 & 15 & 18 & 21 & 24 & mean & 9 & 12 & 15 & 18 & 21 & 24 & mean \\
\hline 9 & 0 & 10 & 13 & 46 & 90 & 92 & 42 & 116 & 101 & 83 & 69 & 63 & 53 & 81 \\
\hline 12 & 15 & 19 & 19 & 63 & 88 & 79 & 47 & 100 & 92 & 76 & 65 & 57 & 50 & 73 \\
\hline 15 & 33 & 48 & 63 & 81 & 71 & 100 & 66 & 79 & 73 & 64 & 58 & 51 & 45 & 62 \\
\hline 18 & 81 & 75 & 84 & 90 & 100 & 100 & 88 & 72 & 65 & 57 & 52 & 47 & 43 & 56 \\
\hline 21 & 94 & 92 & 86 & 100 & 100 & 100 & 95 & 62 & 58 & 52 & 47 & 43 & 39 & 50 \\
\hline 24 & 94 & 90 & 100 & 100 & 100 & 100 & 97 & 56 & 54 & 49 & 44 & 40 & 37 & 47 \\
\hline Mean & 53 & 56 & 61 & 80 & 91 & 95 & 73 & 81 & 74 & 64 & 56 & 50 & 45 & 62 \\
\hline
\end{tabular}

lasted for $12 \mathrm{~h}$ daily. Non-retarded bulbs of 'Wedgwood' produced $100 \%$ flowering of the first bud in all 36 temperature combinations. Differences in blasting percentages of the second bud, however, were great. These are presented in Table 6 , together with the number of days from planting till flowering. The figures demonstrate that the differences in the effects of a comparable change in DT and NT are small on percentage of bud blasting and on time of flowering. On an average an increase during the day stimulated bud blasting a little more than an increase during the night. In preceding experiments with retarded and non retarded bulbs (not presented), no difference was found and in one case even a greater effect of a temperature increase during the night. However, in all experiments time of flowering was mainly determined by the average daily temperature.

Table 7 presents the blasting percentages of the first and second bud in a similar experiment with retarded bulbs of 'Wedgwood'. In this case the effects of DT and NT on time of flowering were similar but on bud blasting they were much different. An increase of temperature during the day was definitely more harmful than an increase during the night. Of the first buds a smaller number blasted than of the second buds, but in both cases the relation between temperature and blasting percentage was similar.

The difference in both experiments regarding the effects of DT and NT becomes

Table 7. Effect of day and night temperature (DT, NT) on percentage of blasting of 1st and 2 nd bud. Storage at $30^{\circ} \mathrm{C}+7$ weeks at $17^{\circ} \mathrm{C}$; planted $69-06-23 ; 54$ 'Wedgwood' bulbs per treatment; $12 \mathrm{~h}$ light per day of $40 \mathrm{~W} \mathrm{m-2}$.

\begin{tabular}{|c|c|c|c|c|c|c|c|c|c|c|c|c|}
\hline \multirow{2}{*}{$\begin{array}{l}\text { DT } \\
\left({ }^{\circ} \mathrm{C}\right)\end{array}$} & \multicolumn{6}{|c|}{ Blasting $(\%)$ st bud at $\ldots{ }^{\circ} \mathrm{C}$ NT } & \multicolumn{2}{|c|}{ Blasting $(\%$} & \multicolumn{4}{|c|}{ 2nd bud at $\ldots{ }^{\circ} \mathrm{C}$ NT } \\
\hline & 12 & 15 & 18 & 21 & 24 & mean & 12 & 15 & 18 & 21 & 24 & mean \\
\hline 12 & 0 & 0 & 0 & 2 & 7 & 2 & 6 & 33 & 30 & 69 & 98 & 47 \\
\hline 15 & 0 & 0 & 21 & 20 & 48 & 18 & 26 & 52 & 88 & 98 & 100 & 73 \\
\hline 18 & 10 & 37 & 28 & 67 & 97 & 44 & 79 & 100 & 94 & 100 & 100 & 95 \\
\hline 21 & 50 & 74 & 83 & 83 & 100 & 78 & 100 & 100 & 100 & 100 & 100 & 100 \\
\hline 24 & 75 & 93 & 98 & 100 & 100 & 93 & 100 & 100 & 100 & 100 & 100 & 100 \\
\hline mean & 27 & 41 & 46 & 54 & 66 & 47 & 62 & 77 & 82 & 93 & 100 & 83 \\
\hline
\end{tabular}




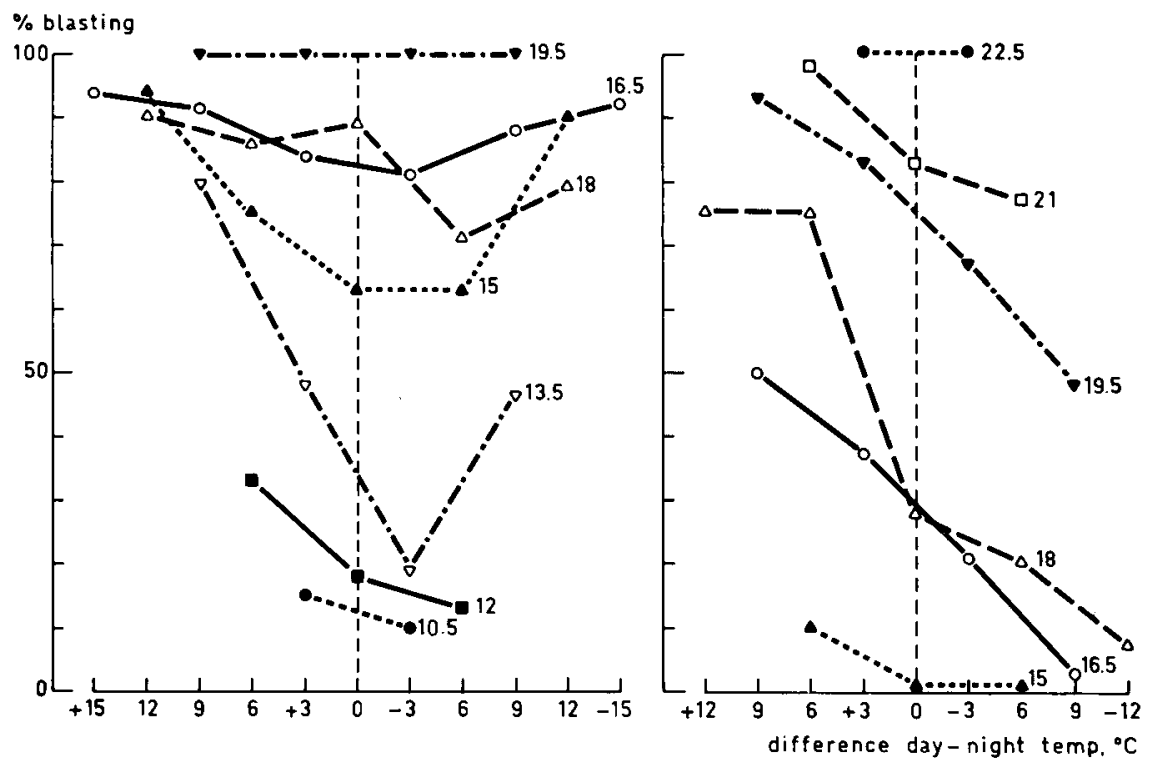

Fig. 2. Relation between a decreasing positive and increasing negative difference between a 12-h day and night temperature on percentage of blasted flower buds, for different averages of both temperatures indicated at the curves. Curves at the left side refer to percentage of blasting of the 2 nd bud from Table 6, those at the right side refer to percentage of blasting of the 1 st bud from Table 7 .

clear in Fig. 2. It shows the relation between blasting percentage and a positive or negative difference between DT and NT for treatments with equal average daily temperatures, indicated on each curve. The left group of curves represents the results of the first experiment, the group on the right those of the second one. Both groups demonstrate that bud blasting increases with: 1) a higher daily temperature, given similar differences between DT and NT; 2) a larger positive difference between DT and NT, given similar daily averages. However, at a larger negative difference, the first experiment demonstrates also an increase of bud blasting whereas the second experiment shows a decrease. The latter indicates that in some cases an equal decrease of DT and increase of NT may diminish bud blasting, even in spite of the development of a negative difference between DT and NT. Both experiments clearly show that in general an increase of DT as well as of NT is detrimental, but an increased NT is sometimes less harmful than an increased DT.

Discussion. The incidental greater influence on bud blasting of an increase in DT compared with an increase in NT is quite unexpected, but in accordance with results of Kamerbeek \& Beyer (1964) and Kamerbeek (1966). They reported that an increase of DT from 15 to $23{ }^{\circ} \mathrm{C}$ augmented bud blasting from 10 to $75 \%$, while a similar increase of NT diminished bud blasting from 10 to $0 \%$. This is the more remarkable because the day period was only $8 \mathrm{~h}$ (Kamerbeek, pers. commun.). On the basis of these results they considered an increase of NT as a more promising method to accelerate flowering than an increase of DT. Taking the difference in duration of DT and NT into account, one can calculate from their data that the effect of an increase 
of either DT or NT on the flowering date is about the same, which supports our results.

Wassink \& Wassink-van Lummel (1952) investigated the effects of lowering NT, expecting that this would have a favourable influence on the energy balance by reducing the rate of dissimilation. This could lead to a lower total light requirement and thus to a decreased blasting at a given light intensity. However, the results failed to show any appreciable effect. This probably supports the above-mentioned results of Kamerbeek \& Beyer. Nevertheless, van de Nes (1962) recommended a lowering of NT rather than DT to prevent bud blasting.

In a discussion of these contradicting results, J. F. Bierhuizen suggested that differences in the plant water status caused by differences in air and soil temperature, could be involved. A change in air temperature may cause a difference in air humidity and soil temperature. These secondary changes could induce differences in the requirement for and availability of water. Hartsema \& Luyten (1961) found that a water shortage could induce bud blasting. Therefore, we had to consider the fact that during the research we gradually changed from dune sand as a medium for rooting to an organic pot soil, which adapts itself more slowly to air temperature. With this in mind we started to investigate the effect of soil temperature. It did not seem very likely that the increased bud blasting at high temperature was caused by a water stress due to a decreased humidity of the air. In that case more light would not have had a beneficial effect.

\section{Comparison of air and soil temperature effects}

Soil temperature (ST) lags increasingly behind a change in air temperature (AT) as pot size increases and as pot soil contains less sand or moisture. A positive difference between day and night temperature may therefore result in a positive difference between AT and ST during part of the daytime and a negative difference during part of the night. The reverse is true when the day temperature is lower than the night temperature. A positive difference between $\mathrm{AT}$ and $\mathrm{ST}$ during daytime is the particular condition for the occurrence of a water stress in the plant. This will be more likely to occur when the day is short and the difference between day and night temperature is large, because of the greater fall in ST during the long and cool night.

To verify this hypothesis, plants of 'Wedgwood' and 'Ideal' were grown in the open under a plastic cover. Only the temperature of the pot soil was regulated and changed every $12 \mathrm{~h}$ between 8 and $18^{\circ} \mathrm{C}$ with an adaptation period of about $2 \mathrm{~h}$. Four groups were distinguished with a change to the higher temperature at $0600,1000,1400$ and 1800 , respectively. Evapotranspiration was measured. Since no space was available in the phytotron, the experimental approach was not as ideal as could be. Besides, the third group did not flower at all due to a short period of overheating. Percentage of blasted second buds and days to flowering are presented in Table 8 . The results support our expectation; bud blasting increased as the change in soil temperature was less synchronized with the change in air temperature. Time of flowering was not affected and the expected differences in transpiration were not found.

Table 9 presents the results with retarded 'Wedgwood' grown at combinations of three constant air and soil temperatures. Because of its possible relation to bud blast, the new bulb weight at time of flowering has been included. Bud blasting and speed of flowering increased with an increase of each of the temperatures, but the effect of AT was much greater. The deviating high value of $76 \%$ at $21{ }^{\circ} \mathrm{C}$ AT and $15{ }^{\circ} \mathrm{C} \mathrm{ST}$ could have been caused by the large positive difference between AT and ST. The 
Table 8. Effect of an $8^{\circ} \mathrm{C}$ and $18^{\circ} \mathrm{C}$ soil temperature, changing every $12 \mathrm{~h}$ at different times of the day, on blasting $\%$ and days to flowering of 'Wedgwood' and 'Ideal'. Storage at $30^{\circ} \mathbf{C}+1$ week at $17{ }^{\circ} \mathrm{C}+7$ weeks at $9{ }^{\circ} \mathrm{C}$; planted $71-03-29$ in a $15{ }^{\circ} \mathrm{C}$ greenhouse; 24 bulbs per treatment and cultivar; 71-04-13 placed outside at controlled soil temperatures.

\begin{tabular}{|c|c|c|c|c|}
\hline \multirow{2}{*}{$\begin{array}{l}\text { Time of change } \\
\text { from } 8 \text { to } 18{ }^{\circ} \mathrm{C}\end{array}$} & \multicolumn{2}{|c|}{ Blasting (\%) of 2 nd bud } & \multicolumn{2}{|c|}{ Days to flowering of 1 st bud } \\
\hline & 'Wedgwood' & 'Ideal' & 'Wedgwood' & 'Ideal' \\
\hline 0600 & 42 & 61 & 48 & 49 \\
\hline 1000 & 42 & 67 & 48 & 49 \\
\hline 1400 & $\dagger$ & $\dagger$ & $\grave{\dagger}$ & $\dagger$ \\
\hline 1800 & 61 & 92 & 47 & 48 \\
\hline
\end{tabular}

Table 9. Effect of constant air and soil temperatures (AT, ST) on percentage of blasting of 1st bud, days to flowering and on new bulb weight at flowering time of plants with ( + ) and without (-) flowers. Storage at $30^{\circ} \mathrm{C}+6$ weeks at $17^{\circ} \mathrm{C}$; planted $67-05-25 ; 54$ bulbs of 'Wedgwood' per treatment; $8 \mathrm{~h}$ light per day of $40 \mathrm{~W} \mathrm{~m}-2$.

\begin{tabular}{|c|c|c|c|c|c|c|c|c|}
\hline \multirow{2}{*}{$\begin{array}{l}\mathrm{AT} \\
\left({ }^{\circ} \mathrm{C}\right)\end{array}$} & \multicolumn{4}{|c|}{ Blasting $(\%)$ at $\ldots{ }^{\circ} \mathrm{C} \mathrm{ST}$} & \multicolumn{4}{|c|}{ Days to flowering at $\ldots{ }^{\circ} \mathrm{C} \mathrm{ST}$} \\
\hline & 15 & 18 & 21 & mean & 15 & 18 & 21 & mean \\
\hline 15 & 10 & 17 & 23 & 17 & 55 & 49 & 46 & 50 \\
\hline 18 & 26 & 36 & 69 & 44 & 46 & 45 & 44 & 45 \\
\hline 21 & 76 & 46 & 72 & 65 & 38 & 35 & 32 & 35 \\
\hline Mean & 37 & 33 & 55 & 42 & 46 & 43 & 41 & 43 \\
\hline \multirow{2}{*}{$\begin{array}{l}\text { AT } \\
\left({ }^{\circ} \mathrm{C}\right)\end{array}$} & \multicolumn{4}{|c|}{ Weight $(+)(\mathrm{mg})$ at $\ldots{ }^{\circ} \mathrm{C} \mathrm{ST}$} & \multicolumn{4}{|c|}{ Weight $(-)(\mathrm{mg})$ at $\ldots{ }^{\circ} \mathrm{C}$ ST } \\
\hline & 15 & 18 & 21 & mean & 15 & 18 & 21 & mean \\
\hline 15 & 164 & 226 & 278 & 223 & 392 & 401 & 706 & 500 \\
\hline 18 & 125 & 185 & 136 & 149 & 215 & 315 & 404 & 311 \\
\hline 21 & 75 & 149 & 278 & 180 & 50 & 252 & 391 & 231 \\
\hline Mean & 121 & 187 & 231 & 167 & 219 & 323 & 500 & 347 \\
\hline
\end{tabular}

daughter bulb weight of flowering plants $(+)$ was smaller than of those which did not flower (-). In both groups there was a positive correlation of bulb weight with ST and a negative correlation with AT.

Discussion. Wassink \& Wassink-van Lummel (1952) already stated that the possible effects of soil temperatures differing from air temperatures should not be overlooked. Kamerbeek (1963a) found that an increase in root temperature from 13 to $18{ }^{\circ} \mathrm{C}$ increased bud blasting from 10 to $73 \%$. Cathey (1954), however, mentioned $18{ }^{\circ} \mathrm{C}$ as the best soil temperature. Durieux (1972a) stated that 'Wedgwood' and 'Ideal' are less susceptible to high soil temperatures than 'Prof. Blaauw'. He recommended special storage temperatures to decrease this susceptibility. Our conclusion is that lowering the soil temperature may decrease bud blasting, provided the difference with air temperature is not too large. Our supposition that a positive difference between AT and ST is particularly detrimental during daytime, has to be investigated. This may well be the 
reason of the observed greater susceptibility to an increase in temperature during the daytime as compared with an increase during the night.

The observed differences in bulb weight at flowering time indicate that bud blast may also be caused by early growth of the bulb, which competes with the flower for the available assimilates. The possibility that an advanced development of the daughter bulb is a cause rather than a result of bud blast, deserves more attention. The negative effect of an excessive leaf growth is no longer overlooked.

\section{The total sum of temperature until flowering}

It was shown earlier that time of flowering is almost independent of light and mainly determined by the average daily temperature $T a$. This suggests that time of flowering could be expressed as the number of days $D$ at which a specific temperature sum $T s$ is reached, taking into account the ineffective temperatures below a specific minimum temperature $T m$. As $D$ is known for a large number of $T a, T s$ and $T m$ can be calculated with the formula $T s=(T a-T m) D$. After conversion, the formula becomes $T a=T s \times 1 / D+T m$, a straight line representing a linear relation between $T a$ and the reciprocal of $D$. The line crosses the ordinate $T a$ at $T m$, and makes an angle with the abscissa $1 / D$ of which the tangent is $T s$.

Fig. 3 presents the relation between $1 / D$ and $T a$ for four of our temperature experiments with 'Wedgwood'. The relation is clearly linear, proving that date of flowering of each group is indeed determined by the temperature sum. However, this heat-sum is different for each group and diverges from about 400 to 900 degree days, while the minimum temperature ranges from 3 to $6^{\circ} \mathrm{C}$.

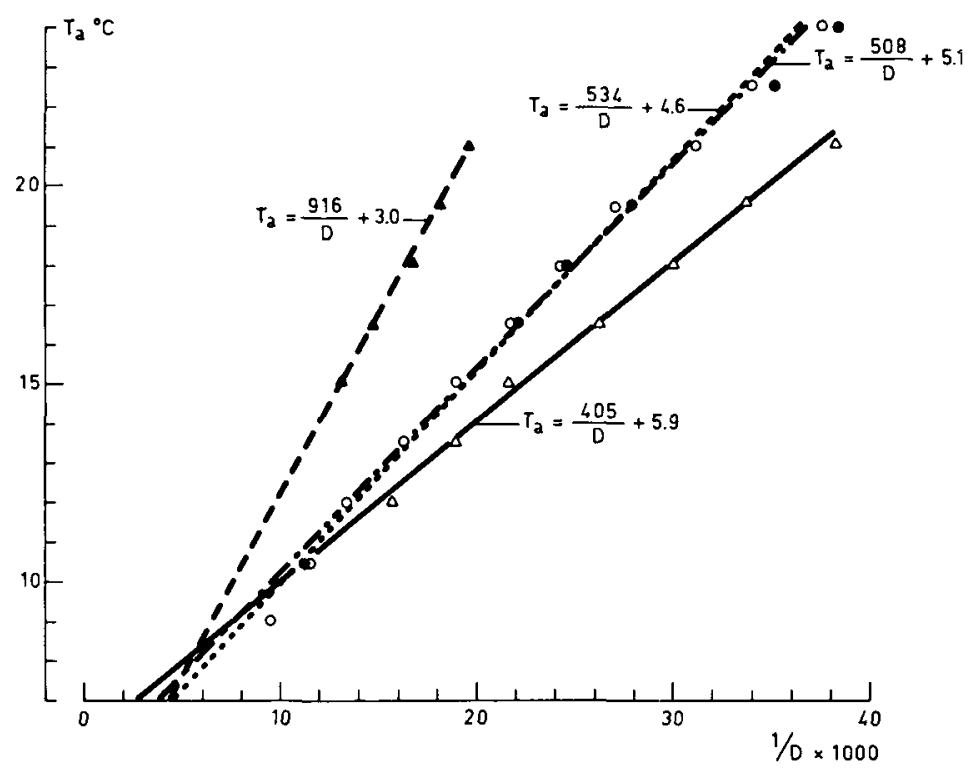

Fig. 3. Relation between the average daily forcing temperature ( $\mathrm{Ta}$ ) and the inverse of number of days to flowering $(D)$, for four experiments with 'Wedgwood' in different years. The formulas are explained in the text. 


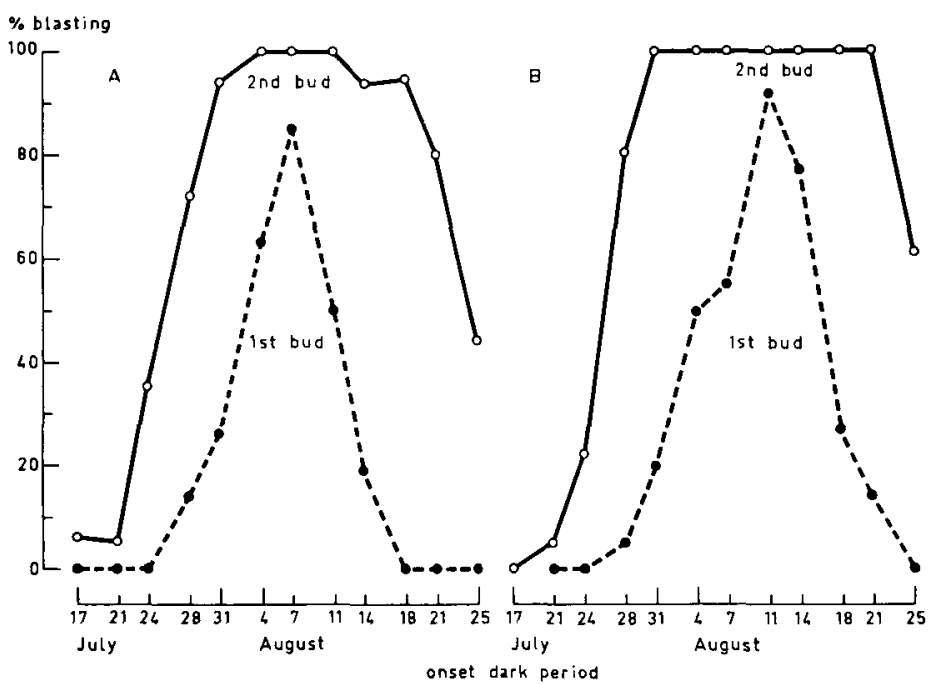

Fig. 4. Effect of a successive intercalation during growth of a four day period in darkness at $24^{\circ} \mathrm{C}$, on the blasting percentage of 1 st and 2 nd bud in two groups of 'Wedgwood' plants, planted 70-06-23 (A) and 70-06-27 (B) and grown in daylight at $15^{\circ} \mathrm{C}$. Storage at $30^{\circ} \mathrm{C}+6$ weeks at $17{ }^{\circ} \mathrm{C} ; 24$ bulbs per treatment.

Discussion. The preceding results indicate that the heat-sum until flowering differs for each planting. Therefore, it is not useful under all circumstances to program flower production, even for one cultivar. Fig. 3 shows that the heat-sum decreases with an increase of minimum temperature, which indicates that differences in growth vigour existed, possibly because of differences in preparation of the bulbs. It is likely that blasting itself is not related to the heat-sum, but to daily temperature only.

\section{The critical period for bud blasting}

In the preceding discussions of the importance of different environmental factors, the period from sprouting till flowering was without an exception treated as a whole. To gain a deeper insight, similar studies have to be undertaken for successive short periods in the development of the plant. This would inform us whether and how temperature and light requirement for flowering change with time. To find the developmental stage most susceptible for blasting, two lots (A and B) of retarded 'Wedgwood' bulbs were planted 4 days after each other in daylight at $15^{\circ} \mathrm{C}$. After sprouting, groups of 24 plants of each lot were transferred successively to darkness at $24{ }^{\circ} \mathrm{C}$ and returned to the original conditions after 4 days. From an untreated group 10 plants were harvested weekly for various measurements of the stage of development reached. Percentages of blasted first and second buds for each of the successive treatments are presented in Fig. 4, for both lots.

The curves show that the effect of 4 days darkness at $24{ }^{\circ} \mathrm{C}$ on blasting increased with time, and then decreased. The susceptibility of the second bud follows a similar curve but is greater than that of the first bud. The curve representing the first bud reaches an 
optimum in the seventh period (7 August) of Lot $\mathrm{A}$ and 4 days later in the eighth period (11 August) of Lot B, thus indicating the same stage of development during which the plant is particularly sensitive. The curves representing the first and second bud in particular, demonstrate that susceptibility to bud blasting exists over a much longer period, i.e. at all stages of development. From the other observations it could be concluded that most blasting occurred in the group treated at the moment of optimum stem elongation when the bud just became visible. This was $31 / 2$ weeks before flowering. In this group the first and second bud had reached a length of about 40 and $15 \mathrm{~mm}$, respectively.

Discussion. Hartsema \& Luyten (1953, p. 103) already stated that supplementary light should be given at least 40 days before flowering. They worked with 'Imperator' which requires more time to flower than 'Wedgwood'. The existence of a period during which iris is most susceptible for bud blasting could mean that a loss of flowers under marginal forcing conditions can be prevented by a slight lowering of temperature or a moderate increase of light intensity during a short period, if applied at the right time.

\section{Main conclusions}

1. Bud blasting after planting of bulbs potentially able to flower is mainly caused by too high temperatures and too low light energies.

2. Temperatures and light requirements change with the stage of plant development and are difficult to predict, because many other factors are involved, such as forcing time, storage and pre-harvest conditions, bulb size and cultivar.

3. The developmental stage during which the plant is most susceptible for the occurrence of bud blast, coincides with the period of the most rapid elongation, i.e. at the moment when the bud just becomes visible.

4. In the range of 9 to $24^{\circ} \mathrm{C}$ a higher temperature accelerates flowering and increases the daily amount of light required to prevent bud blasting.

5. Within certain limits the distribution of the required daily light energy brought about by intensity and duration is of no importance for percentage and time of flowering.

6. The effect of day and night temperature on percentage as well as on time of flowering is about the same. Cases where the influence of the day temperature was greater than that of the night temperature could be explained by other factors, such as an insufficient adaptation of soil temperature to air temperature.

7. Bud blasting increases at high soil temperatures. Air temperature has a greater influence than soil temperature. In addition, bud blasting is promoted by a large positive difference between air and soil temperature, perhaps during daytime in particular.

8. Total light requirement till flowering is lowest at a specific combination of temperature and light intensity, depending on the acceptable percentage of flowering. 9. Time of flowering is determined by a specific heat-sum for each planting. Heat-sum and minimum temperature differ with each group and have no effect on bud blasting. 10. The physiological background of blasting is largely unknown. Internal competition for the assimilates plays an important role. The hypothesis that early development of the daughter bulbs is a cause rather than a result of bud blasting deserves more attention. 


\section{Acknowledgment}

The contribution to this work by the former students B. Boerboom, H. C. Smid-Ter Haar, H. P. Pasterkamp and H. Verboom is gratefully acknowledged. We thank J. Doorenbos and G. A. Kamerbeek for their critical reading of the manuscript.

\section{References}

Beyer, J. J., 1952. Experiments on the retardation of Dutch Irises. Acta bot. neerl. 1: $268-286$.

Blaauw, A. H., 1934. De grenzen der bloeibaarheid bij bol-irissen. I. Proc. Kon. Akad. Wet. 37: 633-643.

Blaauw, A. H., 1935. Het groeien van den iris-bol na verschillende zomerbehandeling. I. Proc. Kon. Akad. Wet. 38: 248-257.

Blaauw, A. H., 1941. On the relation between flower formation and temperature (bulbous irises). Proc. Kon. Akad. Wet. 44: 513-520, 684-689.

Blaauw, A. H., I. Luyten \& A. M. Hartsema, 1936a. Snelle bloei van Hollandse irissen. I. Proc. Kon. Akad. Wet. 39: 604-612.

Blaauw, A. H., I. Luyten \& A. M. Hartsema, 1936b. De grenzen der bloeibaarheid en het groeien van den iris-bol. II. Proc. Kon. Akad. Wet. 39: 1-14.

Cathey, H. M., 1954. Effect of air and soil temperature on the flowering of the 'Wedgwood' iris. N.Y. State Flow. Grow. Bull. 106: 3-4.

Doorenbos, J., 1964. Het fytotron van het Laboratorium voor Tuinbouwplantenteelt der Landbouwhogeschool. Meded. Dir. Tuinb. 27: 432-437.

Durieux, A. J. B., 1972a. Hoge bodemtemperatuur en de bloei van geremde irissen. Bloemboll. Cult. 82: $1248-1249$

Durieux, A. J. B., 1972b. Ondanks later planten is goede bloei van geremde 'Prof. Blaauw' en 'Ideal' mogelijk door gewijzigde nabehandeling. Bloemboll. Cult. 82: 1272-1274.

Elliott, F. E., 1943. Blindness in irises. Flor. Rev. 2399.

Halevy, A. H., J. Shoub, D. Rakati, O. Plesner \& S. P. Monselise, 1963. Effects of storage temperature on development, respiration, carbohydrates content, catalase and peroxidase activity of 'Wedgwood' iris plants. Am. Soc. Hort. Sci. 83: 786-797.

Halevy, A. H., J. Shoub, D. Rakati, 1964. The effects of storage temperature and growing conditions on intermediate size bulbs of 'Wedgwood' iris. Israel J. agric. Res. 14: 11-17.

Hartsema, A. M. \& I. Luyten, 1953. Snelle bloei van Hollandse irissen van 'Imperator'. IV. Invloed van temperatuur ên licht. Proc. Kon. Akad. Wet. C56: 81-105.

Hartsema, A. M. \& I. Luyten, 1955a. Snelle bloei van iris 'Wedgwood' II. Invloed van temperatuur en licht. Proc. Kon. Akad. Wet. C58: 462-488.

Hartsema, A. M. \& I. Luyten, 1955b. Early flowering of Dutch Iris 'Imperator'. V. Light intensity and daylength. Acta bot. neerl. 4: 370-375.

Hartsema, A. M. \& I. Luyten, 1961. Snelle bloei van iris 'Wedgwood'. III. Analyse van de licht- en waterbehoefte. Proc. Kon. Akad. Wet. C64: 600-629.

Hartsema, A. M. \& I. Luyten, 1962. Snelle bloei van Hollandse irissen 'Imperator'. VI. Lichtbehoefte na verschillende prepareerbehandelingen. Proc. Kon. Akad. Wet. C65: 1-21.

Kamerbeek, G. A., 1962. Respiration of the iris bulb in relation to the temperature and the growth of the primordia. Acta bot. neerl. 11: $331-410$.

Kamerbeek, G. A., 1963a. Vroege bloei van iris 'Wedgwood'. Versl. Lab. BloembOnderz, Lisse: 17-19.

Kamerbeek, G. A., 1963b. Temperature treatment of Dutch iris in relation to the development. Rep. 1st int. Symp. Iris (Florence): 459-475.

Kamerbeek, G. A., 1965. Fysiologie en bloembollenteelt. Meded. Dir. Tuinb. 28: 337-342.

Kamerbeek, G. A., 1966. Influence of light, temperature and other factors on bud blast of Dutch irises. Proc. 17th int. hort. Congr. (Maryland) Vol. 1, No 233.

Kamerbeek, G. A., 1969. Influence of light and temperature on flower-bud development in buibous irises (Iris cv. 'Wedgwood') and lilies (Lilium cv. 'Enchantment'). Acta Hort. 14: 175-176.

Kamerbeek, G. A. \& J. J. Beyer, 1964. Vroege bloei van Iris 'Wedgwood'. Meded. Dir. Tuinb. 27: $598-604$.

Kimura, Y. \& N. W. Stuart, 1972. Exponential nature of heat exposure duration relative to temperature change in the curing and flowering of bulbous iris. J. Am. Soc. hort. Sci. 97: 424-426.

Luyten, I., 1942. De bloemaanleg van Iris tingitana Boiss. et Reuter. Meded. LandbHogesch. Wageningen. 46: 1-328. 
Mayak, S. \& A. H. Halevy, 1971. Water stress as the cause of failure of flower bud opening in. Iris. Proc. Am. Soc. hort. Sci. 96: 482-484.

Nes, A. G. van de, 1962. Vroegbloei bij iris 'Wedgwood'. Jversl. Proefstn Groente- en Fruitteelt Glas, Naaldwijk: 29-30.

Rees, A. R., 1972. The growth of bulbs. Applied aspects of the physiology of ornamental bulbous crop plants. Academic Press, London, 311 pp.

Rodrigues Pereira, A. S., 1970. The effect of CCC on growth and endogenous growth substances in 'Wedgwood' iris. Acta. bot. neerl. 19: 895-901.

Stuart, N. W., S. Asen \& C. J. Gould, 1966. Accelerated flowering of bulbous iris after exposure to ethylene. Hort. Sci. 1: 19-20.

Stuart, N. W. \& C. J. Gould, 1967. New directions in forcing bulbous iris. Abstr. 64th A. Meet. Am. Soc. hort. Sci. (Texas ASM Univ.): 58-59.

Stuart, N. W., C. J. Gould, \& D. L. Gill, 1955. Effect of temperature and other storage conditions on forcing behaviour of Easter lilies, bulbous iris and tulips. Rep. 15th int. hort. Congr. (Netherlands): 173-187.

Walla, I. \& T. Kristoffersen, 1969. Some factors affecting the result of early forcing of Iris $\times$ Hollandica 'Wedgwood'. Acta Hort. 14: 187-191.

Wassink, E. C., 1961. Some aspects of photocontrol of plant growth and development. In: Recent advances in botany, p. 42-47. University of Toronto Press.

Wassink, E. C., 1969. Effects of light intensity on dry matter production and morphogenesis of Iris 'Wedgwood' as compared with Gladiolus and tulip. Meded. LandbHogesch. Wageningen 69: 1-17.

Wassink, E. C. \& L. E. A. Wassink-Van Lummel, 1952. The action of light intensity and night temperature on flowering of bulbous irises 'Wedgwood' and tulips. Rep. 13th int. hort. Congr. (London): 969-981.

Wassink, E. C. \& C. van der Scheer, 1951. A spherical radiation meter. Meded. LandbHogesch.. Wageningen. $51: 175-183$. 